\title{
Ultra-Marathon-Induced Increase in Serum Levels of Vitamin D Metabolites: A Double-Blind Randomized Controlled Trial
}

\author{
Jan Mieszkowski ${ }^{1}{ }^{\circledR}$, Błażej Stankiewicz ${ }^{2}$, Andrzej Kochanowicz ${ }^{1}$, \\ Bartłomiej Niespodziński ${ }^{2}$, , Tomasz Kowalik ${ }^{2}$, Michał A. Żmijewski ${ }^{3}$, Konrad Kowalski ${ }^{4}$, \\ Rafał Rola ${ }^{4,5}$, Tomasz Bieńkowski ${ }^{4}$ and Jędrzej Antosiewicz ${ }^{6, *}$ (D) \\ 1 Department of Gymnastics and Dance, Gdansk University of Physical Education and Sport, \\ 80-336 Gdansk, Poland; mieszkowskijan@gmail.com (J.M.); andrzejkochanowicz@o2.pl (A.K.) \\ 2 Institute of Physical Education, Kazimierz Wielki University, 85-064 Bydgoszcz, Poland; \\ blazej1975@interia.pl (B.S.); bartlomiej.niespodzinski@ukw.edu.pl (B.N.); tomasz.kowalik@ukw.edu.pl (T.K.) \\ 3 Department of Histology, Medical University of Gdańsk, 80-211 Gdansk, Poland; \\ michal.zmijewski@gumed.edu.pl \\ $4 \quad$ Masdiag Sp. z o.o. Company, 01-882 Warsaw, Poland; konrad.kowalski@masdiag.pl (K.K.); \\ r.rola@doktorant.umk.pl (R.R.); tomasz.bienkowski@masdiag.pl (T.B.) \\ 5 Chair of Environmental Chemistry and Bioanalytics, Faculty of Chemistry, Nicolaus Copernicus University \\ in Toruń, 87-100 Toruń, Poland \\ 6 Department of Bioenergetics and Physiology of Exercise, Medical University of Gdansk, \\ 80-210 Gdansk, Poland \\ * Correspondence: jant@gumed.edu.pl; Tel.: +48-583491456
}

Received: 20 October 2020; Accepted: 23 November 2020; Published: 25 November 2020

\begin{abstract}
Purpose: While an increasing number of studies demonstrate the importance of vitamin D for athletic performance, the effects of any type of exercise on vitamin D metabolism are poorly characterized. We aimed to identify the responses of some vitamin D metabolites to ultra-marathon runs. Methods: A repeated-measures design was implemented, in which 27 amateur runners were assigned into two groups: those who received a single dose of vitamin $\mathrm{D}_{3}$ $(150,000 \mathrm{IU}) 24 \mathrm{~h}$ before the start of the marathon $(n=13)$ and those $(n=14)$ who received a placebo. Blood samples were collected $24 \mathrm{~h}$ before, immediately after, and $24 \mathrm{~h}$ after the run. Results: In both groups of runners, serum $25(\mathrm{OH}) \mathrm{D}_{3}, 24,25(\mathrm{OH})_{2} \mathrm{D}_{3}$, and 3-epi-25(OH) $\mathrm{D}_{3}$ levels significantly increased by $83 \%, 63 \%$, and $182 \%$ after the ultra-marathon, respectively. The increase was most pronounced in the vitamin D group. Body mass and fat mass significantly decreased after the run in both groups. Conclusions: Ultra-marathon induces the mobilization of vitamin D into the blood. Furthermore, the $24,25(\mathrm{OH})_{2} \mathrm{D}_{3}$ and 3-epi-25(OH) $\mathrm{D}_{3}$ increases imply that the exercise stimulates vitamin D metabolism.
\end{abstract}

Keywords: endurance exercise; 3-epi-25(OH) $\mathrm{D}_{3} ; 24,25(\mathrm{OH})_{2} \mathrm{D}_{3} ; 25(\mathrm{OH}) \mathrm{D}_{3}$

\section{Introduction}

Vitamin D plays a crucial role in the regulation of multiple physiological processes. Its activity is mainly ascribed to the active form, $1,25(\mathrm{OH})_{2} \mathrm{D}_{3}$, which acts via a specific vitamin D receptor (VDR). VDR is a transcriptional factor that regulates the expression of approximately 1000 genes. VDR is present in almost all human tissues [1,2]. Consistently, vitamin D deficiency has been associated with multiple morbidities, such as cancer, diabetes, multiple sclerosis, cardiovascular diseases, and others [3-6]. Therefore, it is recognized that vitamin D status is an important risk factor for several diseases of civilization. Moreover, more and more athletes also show a low vitamin D status, which may negatively impact the health, performance, and training efficiency of athletes $[7,8]$. 
Vitamin D is produced in the skin in response to ultraviolet (sunlight) exposure. Subsequently, it is hydroxylated at positions 25 and 1 to gain full hormonal activity. On the other hand, 25-OH vitamin D $\left[25(\mathrm{OH}) \mathrm{D}_{3}\right]$ is a good marker of vitamin $\mathrm{D}$ status. The kidney, brain, bone, skin, prostate, and white blood cells can convert $25(\mathrm{OH}) \mathrm{D}_{3}$ to its active form $\left[1,25(\mathrm{OH})_{2} \mathrm{D}_{3}\right]$. It can be anticipated that low serum levels of $25(\mathrm{OH}) \mathrm{D}_{3}$ will limit the synthesis of the active form in all these tissues. Serum $25(\mathrm{OH}) \mathrm{D}_{3}$ levels are mainly determined by exposure to sunlight and vitamin D supplementation. In addition, higher fat tissue content is associated with lower serum $25(\mathrm{OH}) \mathrm{D}_{3}$ levels, possibly because of its ability to store vitamin $\mathrm{D}[9,10]$. On the other hand, higher physical activity is associated with better vitamin D status, even though many athletes are vitamin D-deficient [11]. Vitamin D supplementation is the easiest way to correct its deficiency and single high doses have been demonstrated to be effective in short periods [12].

Among many factors, exercise-induced release of vitamin $\mathrm{D}$ from adipose tissue has been postulated as an important mechanism that leads to increased vitamin D levels in the blood [13]. However, the effect of exercise on vitamin D status is not fully understood. Of note, vitamin D metabolism is involved in the formation of other metabolites, such as 3-epi-25(OH) $\mathrm{D}_{3}$ and $24,25(\mathrm{OH})_{2} \mathrm{D}_{3}$. These metabolites are not considered to be physiologically active. However, based on recent studies, they play an important role in the regulation of general metabolism. For example, 3-epi-25(OH) $\mathrm{D}_{3}$ levels are associated with an improved cardiovascular risk profile, and 3-epi-1,25(OH $)_{2} \mathrm{D}_{3}$, derived from 3-epi-25(OH) $\mathrm{D}_{3}$, effectively reduces blood parathormone without inducing changes in the plasma calcium levels $[14,15]$. In addition, $24,25(\mathrm{OH})_{2} \mathrm{D}_{3}$, considered to be an inactive form of vitamin $\mathrm{D}$, protects cells from $1,25(\mathrm{OH})_{2} \mathrm{D}_{3}$ toxicity and modulates the antioxidant potential by binding catalase [16]. Furthermore, studies involving animal models demonstrated that $24,25(\mathrm{OH})_{2} \mathrm{D}_{3}$ plays an important role in normal bone integrity, function, and healing $[17,18]$. Interestingly, high $24,25(\mathrm{OH})_{2} \mathrm{D}_{3}$ levels are associated with a reduced disability status in multiple sclerosis patients [19].

Collectively, the above observations indicate that vitamin D metabolites have important biological functions, which are far from being completely understood. Therefore, it is crucial to study the effects of exercise on vitamin D metabolism. Exercise stimulates the release of several hundreds of proteins (myokines) into circulation from the skeletal muscle while also stimulating the liberation of bioactive proteins (exerkines) from other tissues [20]. An example of such an exerkine is fibroblast growth factor 23, whose concentration increases after exercise [21]. This exerkine is responsible for the regulation of plasma phosphate levels and modifies vitamin D metabolism by inhibiting the formation of $1,25(\mathrm{OH})_{2} \mathrm{D}_{3}$ [22].

Ultra-marathon is a type of exercise that pushes the boundaries of human performance. This extreme type of physical activity, involving continuous running over a distance well above the $42 \mathrm{~km}$ of a regular marathon run, is associated with enormous energy expenditure. Until now, knowledge about vitamin D metabolism associated with strenuous exercise like ultra-marathon has been limited [23]. Running and walking for extreme durations, so-called ultra-marathons, have become increasingly popular in the last years throughout the world, particularly in the USA, Europe, Japan, and South Africa [24]. Hence, it seems important to evaluate the effect of this type of prolonged exercise on the physiological responses of the human body, both under conditions of supplementation and where supplementation is not provided. Especially vitamin D supplementation could prevent exercise-induced inflammation processes and other adverse body reactions. We proposed that ultra-marathon, which alters the production of hundreds of exerkines [25] and has the potential to reduce the amount of adipose tissue [26], influences vitamin D metabolism.

Here, we performed a double-blind randomized controlled trial to determine the impact of extreme endurance exercise on vitamin D metabolites in relation to vitamin D supplementation. We found that ultra-marathon induced a significant increase in metabolites of vitamin $\mathrm{D}_{3}$ which do not possess classical metabolic effects of the active form of vitamin $\mathrm{D}_{3}$. 


\section{Materials and Methods}

\subsection{Experimental Overview}

The study was designed as a double-blind randomized controlled trial with parallel groups. Participants were randomly assigned to two groups: the supplementation group and the control group. The supplementation protocol involved a single high dose of vitamin D3 before the start of the ultra-marathon. During the initial visit, data on the subject's age, body composition, and height were collected. All runners were examined by a professional physician. A sample of venous blood was obtained before the ultra-marathon start and immediately after and $24 \mathrm{~h}$ after the run to evaluate the vitamin D metabolites. Additionally, before starting the actual experiment, to evaluate body responses to a high dose of vitamin D, profiles of vitamin D analogues were assessed. All laboratory analyses were performed at the Gdansk University of Physical Education (Gdansk, Poland).

\subsection{Participants}

Twenty-seven male ultra-marathon runners taking part in the Lower Silesian Mountain Runs Festival Ultra-Marathon Race participated in the study. The runners were randomly assigned to the experimental (supplemented, UM-S; $n=13$ ) and control (placebo, UM-C; $n=14$ ) groups. The characteristics of the groups are shown in Table 1. The participants were physically active ultra-marathon amateur runners. None of the runners had any history of known diseases or reported any intake of medication due to illnesses in six months before the experiment. All runners had previous ultra-marathon race experience (not less than two). During all testing periods and 1 week before testing, the participants refrained from alcohol, caffeine, guarana, theine, tea, chocolate, and any other substance intake which may potentially influence exercise performance. Furthermore, the participants were asked to adopt a similar eating pattern on the days of measurements, based on a randomized diet for their age group and physical intensity. The study protocol was accepted by the Bioethics Committee for Clinical Research at of the Collegium Medicum University of Nicolaus Copernicus (decision number KB-124/2017) and conducted according to the Declaration of Helsinki. The study was registered as clinical trial: NCT03417700. Written informed consent was obtained from all study participants, who were also informed about the possibility of withdrawal of consent at any time and for any reason. Prior to participation, subjects were informed about the study procedures but not about the rationale and study aim, so as to keep them naive about the potential effect of supplementation.

Table 1. Characteristics of the participants $(n=27)$.

\begin{tabular}{lccccc}
\hline \multirow{2}{*}{ Variable } & \multicolumn{2}{c}{ UM-S $(n=\mathbf{1 3})$} & \multicolumn{2}{c}{ UM-C $(\boldsymbol{n}=\mathbf{1 4})$} & \multirow{2}{*}{ Effect Size $\left(\eta^{\mathbf{2}}\right)$} \\
\cline { 2 - 5 } & Mean \pm SD & $\mathbf{( 9 5 \% ~ C I )}$ & Mean \pm SD & $\mathbf{( 9 5 \% ~ C I )}$ & \\
\hline Age (years) & $42.00 \pm 8.44$ & $(36.00-47.00)$ & $40.00 \pm 8.11$ & $(36.00-45.00)$ & 0.01 \\
$\begin{array}{l}\text { Body mass } \\
\text { Body height } \\
(\mathrm{cm})\end{array}$ & $74.29 \pm 7.51$ & $(70.12-78.45)$ & $78.64 \pm 10.66$ & $(72.20-85.09)$ & 0.05 \\
$\begin{array}{l}\text { Body mass } \\
\text { index }\end{array}$ & $174.80 \pm 3.80 *$ & $(172.54-177.45)$ & $181.30 \pm 5.43$ & $(178.43-183.56)$ & 0.34 \\
Fat mass (\%) & $23.92 \pm 2.42$ & $(21.10-25.65)$ & $24.18 \pm 1.83$ & $(22.95-25.41)$ & 0.01 \\
\hline
\end{tabular}

Note: UM-S, runners given vitamin D3; UM-C, runners without vitamin D supplementation (control group). Significant difference at ${ }^{*} p \leq 0.05$.

\subsection{Pilot Study}

Although vitamin D metabolism is well documented, to date, changes in serum levels of vitamin $\mathrm{D}$ metabolites after administration of a high dose of vitamin $\mathrm{D}$ have not been evaluated. To evaluate body responses to a high dose of vitamin D, profiles of vitamin $\mathrm{D}$ analogues were assessed. For this purpose, four physically active non-ultra-marathon runners (volunteers) took two doses of vitamin D3 
(100,000 or 200,000 IU) 28 day apart. The blood samples were taken at selected time points (days 0 to 45) and profiles of vitamin D analogues were analyzed as described in Section 2.6. The following were analyzed: $25(\mathrm{OH}) \mathrm{D}_{3}, 3-e p i-25(\mathrm{OH}) \mathrm{D}_{3}$, and $24,25(\mathrm{OH})_{2} \mathrm{D}_{3}$, and the ratios of the last two compounds to $25(\mathrm{OH}) \mathrm{D}_{3}$.

\subsection{Ultra-Marathon Run}

One day after the first blood sample collection, physician examination, and supplementation, all runners (UM-C and UM-S groups) participated in the Lower Silesian Mountain Run Festival (19 July 2018). The start and finish points were in the town of Lądek Zdrój (Lower Silesian Voivodeship, Poland).

The running festival took place in the Kłodzko Land (latitude of $50^{\circ} \mathrm{N}$ ) and consisted of seven mountain trails, with a maximum course length of $240 \mathrm{~km}$, a maximum altitude of approximately $1425 \mathrm{~m}$ a.s.l., and a minimum altitude of approximately $261 \mathrm{~m}$ a.s.1. The entire altitude range was approximately $1164 \mathrm{~m}$, and the total ascent and descent was $7670 \mathrm{~m}$. (Figure 1). The run started at $18: 00 \mathrm{~h}$ and the temperature during the run varied from $18^{\circ} \mathrm{C}$ at the start point to $4{ }^{\circ} \mathrm{C}$ on the top of the Śnieżnik Mountain. Most of the time, the sky was overcast.

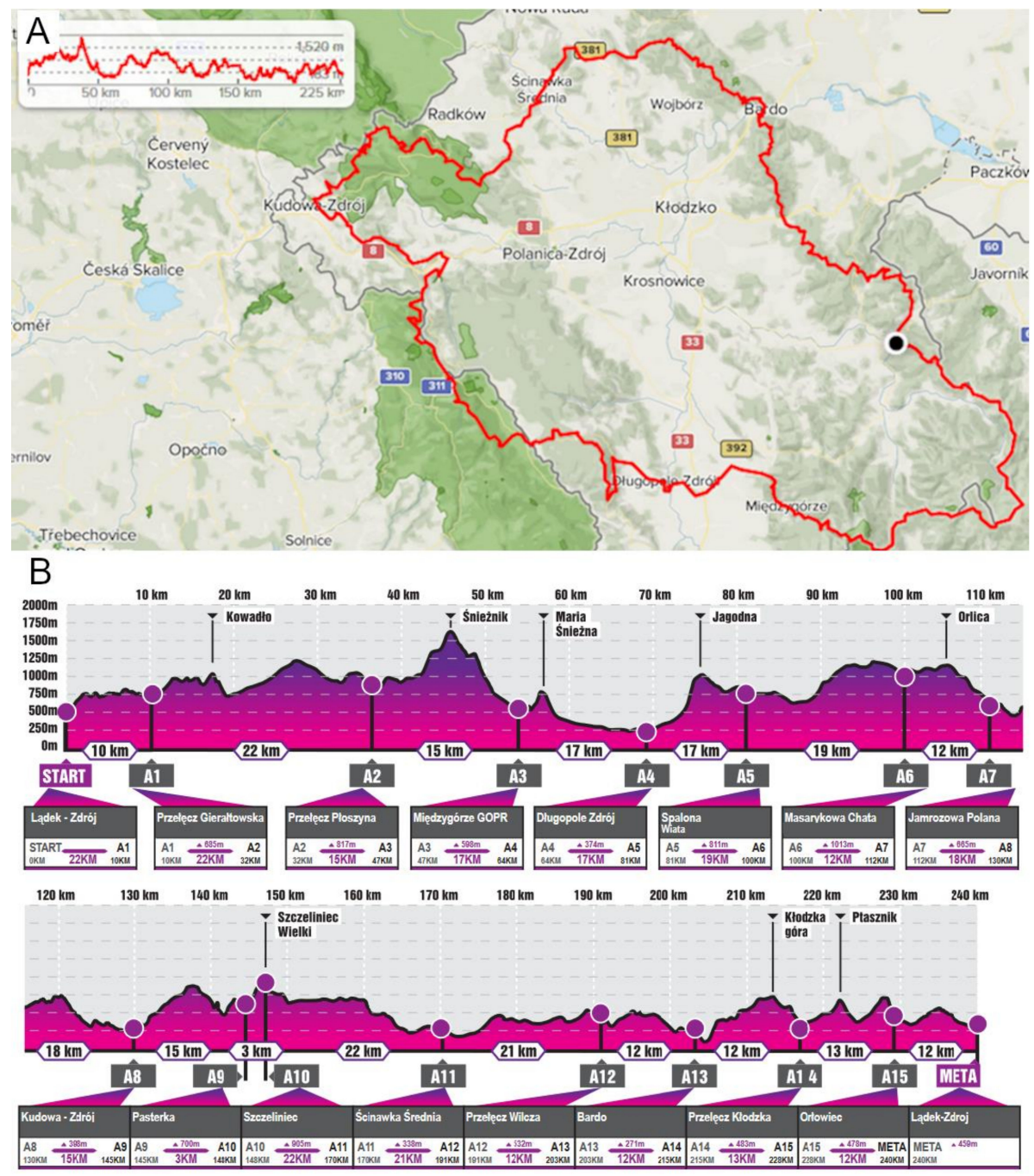

Figure 1. Ultra-marathon track characteristics of the Lower Silesian Mountain Run Festival 2018, Ladek Zdrój. The entire track (A) and select track parts and distances (B) are shown (Mountain Marathons Foundation). 


\subsection{Vitamin D Supplementation}

Each participant from the experimental group received a single high dose of vitamin D3 (150,000 IU) $24 \mathrm{~h}$ before the start of the ultra-marathon. The decision was based on the pilot study, which showed the highest concentration of vitamin D metabolites within $24-48 \mathrm{~h}$. The control group received a placebo solution with the taste (anise), color, and consistency matching those of the vitamin D solution (pure vegetable oil solution).

The participants and researchers had no knowledge of the groups and differences in the supplementation procedures.

\subsection{Sample Collection and Measurements of Vitamin D Metabolite Levels}

Blood (9 mL) was collected three times: $24 \mathrm{~h}$ before and after the race and immediately after the run (up to $5 \mathrm{~min}$ after the run). Venous blood samples were collected into Sarstedt S-Monovette tubes (S-Monovette ${ }^{\circledR}$ Sarstedt AG\&Co, Nümbrecht, Germany) without anticoagulant for serum separation (with a coagulation accelerator). The serum was separated using standard laboratory procedures, aliquoted, and frozen at $-80{ }^{\circ} \mathrm{C}$ until further analysis. Sample preparation was based on serum protein precipitation and derivatization. Quantitative analysis was performed using liquid chromatography coupled with tandem mass spectrometry (QTRAP ${ }^{\circledR} 4500$ (Sciex) coupled with ExionLC HPLC system) with minor changes according to previously published method [27]. Serum samples were analyzed in the positive ion mode, using electrospray ionization. The raw data were collected using Analyst ${ }^{\circledR}$ software, while to process and quantify the collected data MultiQuant ${ }^{\circledR}$ was used. Various reagents were used in the sample preparation procedure. Furthermore, 4-(4'-Dimethylaminophenyl)-1,2,4-triazoline-3,5-dione (DAPTAD) was used as a derivatization agent. It was synthesized by Masdiag Laboratory (Warsaw, Poland). Additionally, solvents such as water, ethyl acetate (POCh S.A., Gliwice, Poland), and methanol (Honeywell, Sigma-Aldrich, Gillingham, Dorset, UK) were used.

Mobile phases were prepared using acetonitrile (ACN) (Honeywell, Sigma-Aldrich, Gillingham, Dorset, UK), water (POCh S.A., Gliwice, Poland), and formic acid (FA) (Merck KGaA, Darmstadt, Germany). All solvents were of LC-MS grade.

The following were determined: $25(\mathrm{OH}) \mathrm{D}_{3}, 24,25(\mathrm{OH})_{2} \mathrm{D}_{3}, 3-e p i-25(\mathrm{OH}) \mathrm{D}_{3}$, and $25(\mathrm{OH}) \mathrm{D}_{2}$ levels and the ratios of $25(\mathrm{OH}) \mathrm{D}_{3}$ to $24,25(\mathrm{OH})_{2} \mathrm{D}_{3}$ and $25(\mathrm{OH}) \mathrm{D}_{3}$ to 3-epi-25(OH) $\mathrm{D}_{3}$. The concentrations of vitamin $\mathrm{D}$ metabolites were corrected to change in plasma volume $[28,29]$.

\subsection{Statistical Analysis}

Descriptive statistics included mean \pm standard deviation (SD) for all measured variables. A two-way ANOVA with repeated measures $(2 \times 3)$ was performed to investigate the impact of ultra-marathon running (marathon: $24 \mathrm{~h}$ before, immediately after, and $24 \mathrm{~h}$ after the run) on vitamin $\mathrm{D}$ metabolites and physical characteristics in relation to vitamin D supplementation (group: UM-S, UM-C). In case of a significant interaction, Tukey's post-hoc test was performed to assess differences in specific subgroups. In addition, the effect size was determined by eta-squared statistics $\left(\eta^{2}\right)$. Values equal to or more than $0.01,0.06$, and 0.14 indicated a small, moderate, and large effect, respectively. All calculations and graphics were conducted using Statistica 12 software (StatSoft, Tulsa, OK, USA). Differences were considered statistically significant when $p \leq 0.05$.

\section{Results}

In the control study, four volunteers who were not participating in any sport activities were given a single high dose of vitamin $\mathrm{D}$ on days 0 and 28, with two doses tested. Regardless of the dose, the $25(\mathrm{OH}) \mathrm{D}_{3}$ and 3-epi-25(OH) $\mathrm{D}_{3}$ levels increased within the first $48-72 \mathrm{~h}$, following which the concentration gradually decreased. A similar relationship was observed for the $24,25(\mathrm{OH})_{2} \mathrm{D}_{3}$ metabolite, with the highest concentration noted between days 4 and 7 after administration. Its levels 
remained relatively constant once the peak was reached. Interestingly, the (slow) increase in the $25(\mathrm{OH}) \mathrm{D}_{3}$ levels began $12 \mathrm{~h}$ after vitamin $\mathrm{D}$ administration, while the $24,25(\mathrm{OH})_{2} \mathrm{D}_{3}$ levels started to increase $24 \mathrm{~h}$ after vitamin $\mathrm{D}$ administration (Figure 2).

A

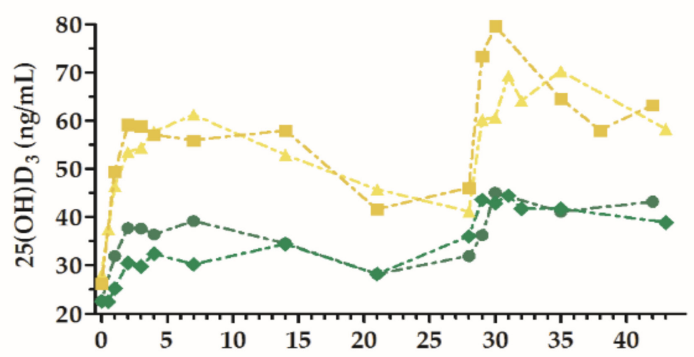

C

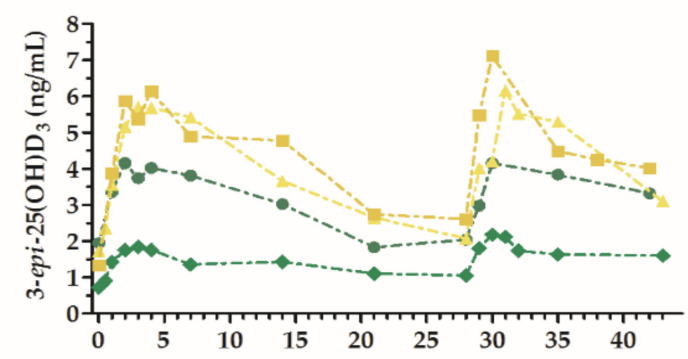

E

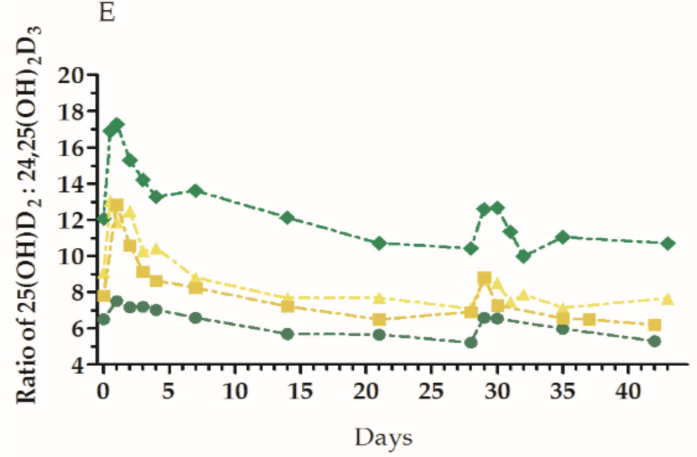

B

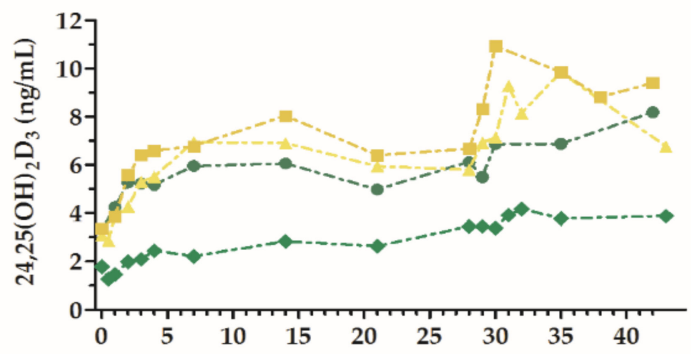

D
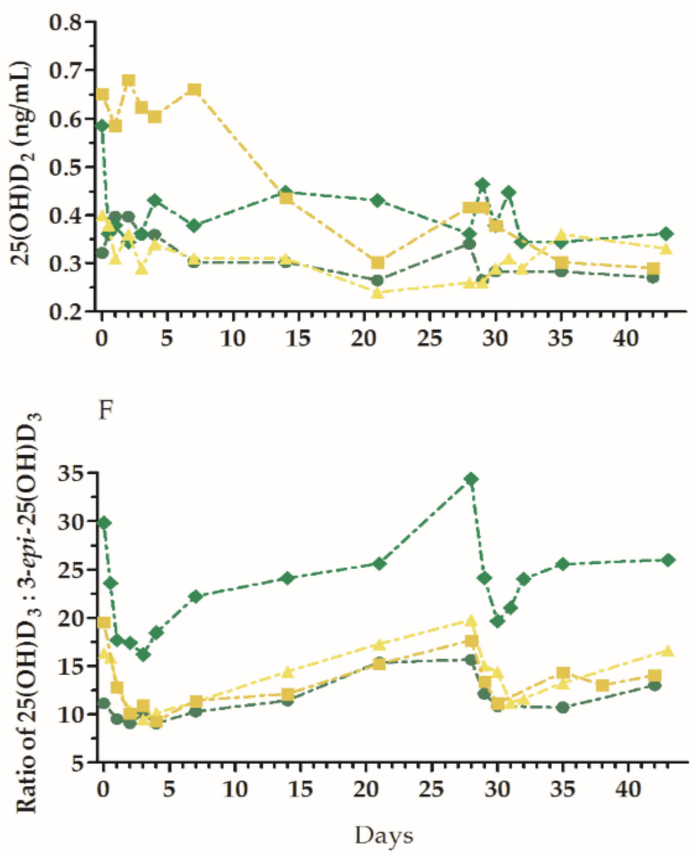

Figure 2. Changes in vitamin D metabolite levels in the serum, and metabolite ratios over time, in four healthy volunteers after receiving two doses of vitamin $\mathrm{D}_{3}$. The doses were given on days 0 and 28. Notation: green lines and symbols-participants administered with 100,000 IU; yellow lines and symbols—participants administered with $200,000 \mathrm{IU}$. The following were determined: $25(\mathrm{OH}) \mathrm{D}_{3}$ levels (A); $24,25(\mathrm{OH})_{2} \mathrm{D}_{3}$ levels $(\mathbf{B}) ; \mathrm{f} 25(\mathrm{OH}) \mathrm{D}_{3}$ levels $(\mathbf{C}) ; 25(\mathrm{OH}) \mathrm{D}_{2}(\mathbf{D})$; ratio of $25(\mathrm{OH}) \mathrm{D}_{3}$ to $24,25(\mathrm{OH})_{2} \mathrm{D}_{3}$ (E); ratio of $25(\mathrm{OH}) \mathrm{D}_{3}$ to 3 -epi- $25(\mathrm{OH}) \mathrm{D}_{3}(\mathbf{F})$.

Changes in the serum levels of vitamin D after the ultra-marathon are presented in Figure 3. The two-way ANOVA revealed a significant ultra-marathon effect in all analyzed variables on serum of vitamin $\mathrm{D}_{3}$ levels (Table 2). Regardless of vitamin $\mathrm{D}_{3}$ supplementation, a significant increase in the levels of $25(\mathrm{OH}) \mathrm{D}_{3}(82.9 \%), 24.25(\mathrm{OH})_{2} \mathrm{D}_{3}(63.3 \%)$, and 3-epi-25(OH)D $(182.6 \%), 25(\mathrm{OH}) \mathrm{D}_{2}(17.7 \%)$ and the ratio of $25(\mathrm{OH}) \mathrm{D}_{3}$ to $24,25(\mathrm{OH})_{2} \mathrm{D}_{3}(45.8 \%)$ was observed, as well as a significant decrease in the ratio of $25(\mathrm{OH}) \mathrm{D}_{3}$ to $3-e p i-25(\mathrm{OH}) \mathrm{D}_{3}(18.4 \%)$ immediately after the ultra-marathon. A significant increase in the levels of $24,25(\mathrm{OH})_{2} \mathrm{D}_{3}, 3$-epi-25(OH) $\mathrm{D}_{3}$, and $25(\mathrm{OH}) \mathrm{D}_{2}$ and the ratios of $25(\mathrm{OH}) \mathrm{D}_{3}$ to $24,25(\mathrm{OH})_{2} \mathrm{D}_{3}$ and $25(\mathrm{OH}) \mathrm{D}_{3}$ to 3-epi-25(OH) $\mathrm{D}_{3}$ was also apparent $24 \mathrm{~h}$ after the ultra-marathon (Table 2). The two-way ANOVA also revealed a significant group effect in $25(\mathrm{OH}) \mathrm{D}_{3}, 3-e p i-25(\mathrm{OH}) \mathrm{D}_{3}$, and $25(\mathrm{OH}) \mathrm{D}_{3}: 24,25(\mathrm{OH})_{2} \mathrm{D}_{3}$ ratio (Table 2). The UM-S group showed a $30.1 \%$ higher concentration 
of $25(\mathrm{OH}) \mathrm{D}_{3}$, a $61.8 \%$ higher concentration of $3-e p i-25(\mathrm{OH}) \mathrm{D}_{3}$, and a $24.7 \%$ higher ratio of $25(\mathrm{OH}) \mathrm{D}_{3}$ to $24,25(\mathrm{OH})_{2} \mathrm{D}_{3}$ in comparison with the UM-C group.

A

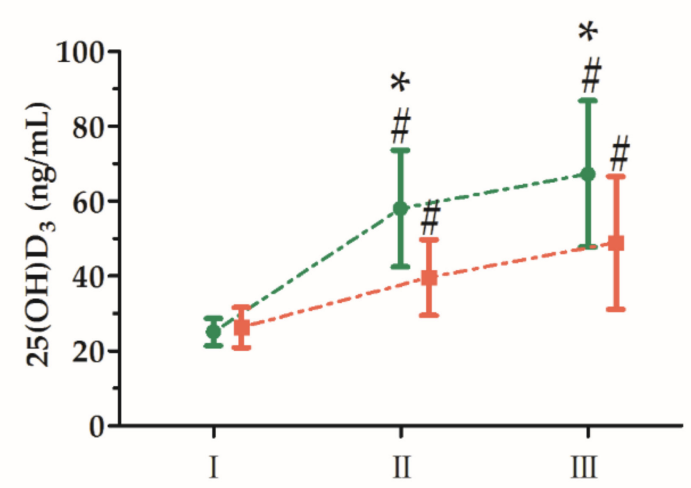

C

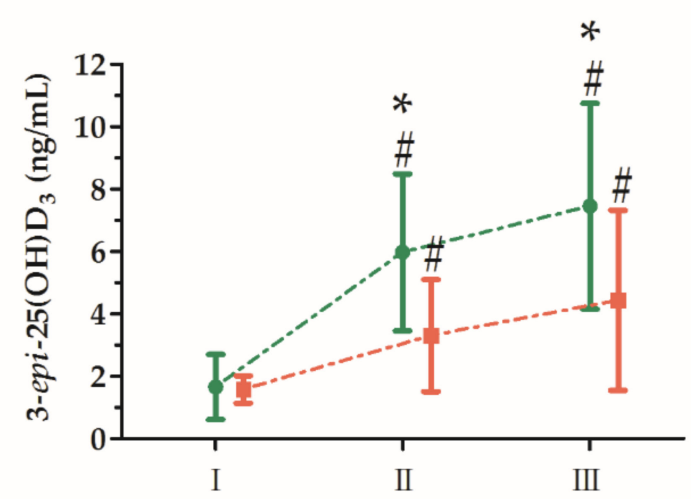

E

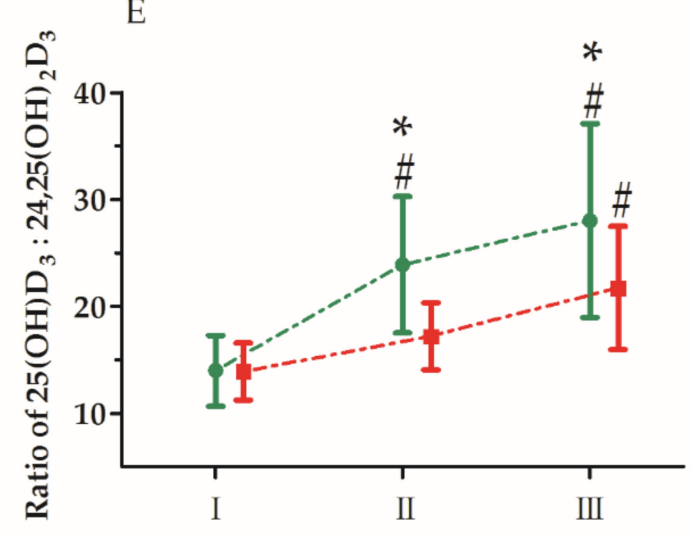

B

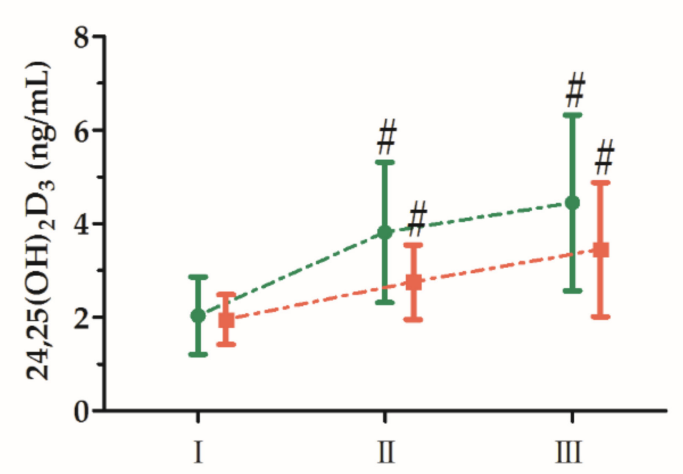

$\mathrm{D}$
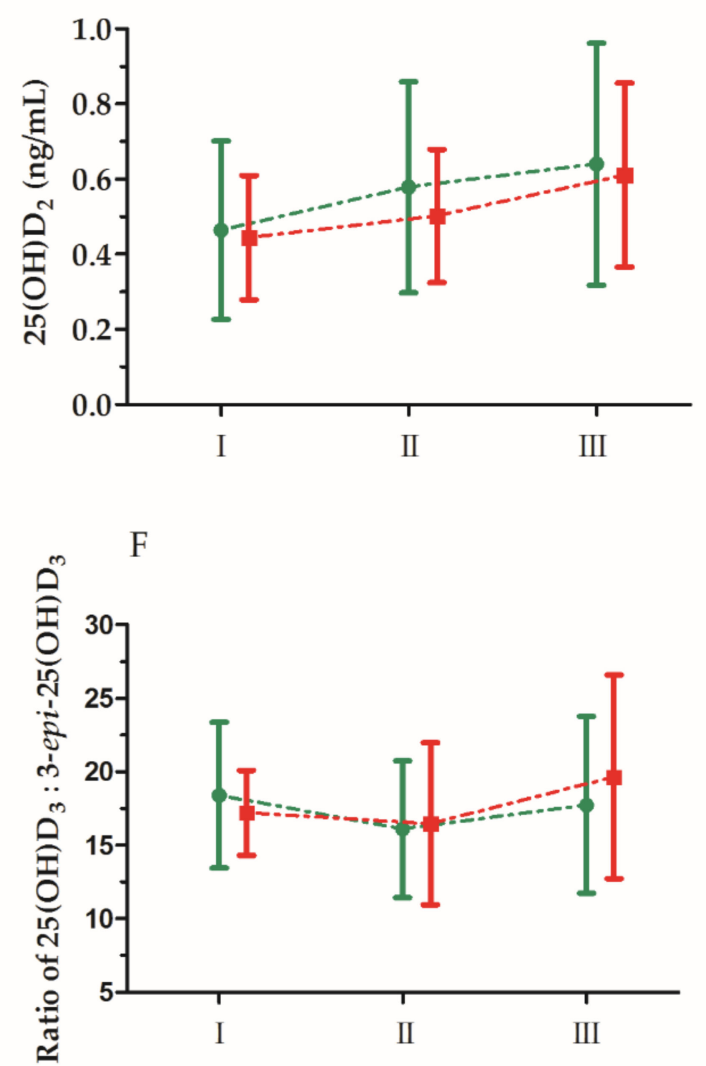

Figure 3. An effect of ultra-marathon on the serum levels of vitamin D metabolites. Data for runners supplemented with vitamin $\mathrm{D}_{3}$ (green symbols and lines) and runners without supplementation (red symbols and lines) are shown. (A) $25(\mathrm{OH}) \mathrm{D}_{3}$ levels; (B) 24,25(OH) ${ }_{2} \mathrm{D}_{3}$ levels; (C) 3-epi-25(OH) $\mathrm{D}_{3}$ levels; (D) 25(OH)D $\mathrm{D}_{2}$ levels; $(\mathbf{E}) 25(\mathrm{OH}) \mathrm{D}_{3}$ : 24,25(OH) ${ }_{2} \mathrm{D}_{3}$ ratio; $(\mathbf{F}) 25(\mathrm{OH}) \mathrm{D}_{3}$ : 3-epi-25(OH) $\mathrm{D}_{3}$ ratio. Time points: I, $24 \mathrm{~h}$ before the ultra-marathon; II, immediately after the ultra-marathon; III, $24 \mathrm{~h}$ after the ultra-marathon. The values are presented as mean \pm SD. * significant difference vs. group without supplementation at $p<0.05 ;{ }^{\#}$ significant difference vs. I time point at $p<0.05$. 
Table 2. Two-way ( 2 groups $\times 3$ repeated measurements) ANOVA of the serum levels of vitamin $\mathrm{D}_{3}$ induced by ultra-marathon run.

\begin{tabular}{|c|c|c|c|c|c|c|}
\hline Variable & Effect & $\mathbf{F}$ & df & $p$ & Effect Size $\left(\eta^{2}\right)$ & Post-Hoc Outcome \\
\hline \multirow{5}{*}{$25(\mathrm{OH}) \mathrm{D}_{3}$} & & & & & & $\mathrm{~S}>\mathrm{C}$ \\
\hline & GR & 6.59 & 1.30 & $0.01 *$ & 0.19 & I < II, III \\
\hline & UM & 67.00 & 2,60 & $0.01 * *$ & $\begin{array}{l}0.19 \\
0.70\end{array}$ & S-I < S-II, S-III \\
\hline & $\mathrm{GR} \times \mathrm{UM}$ & 7.43 & 2,60 & $0.01 * *$ & 0.20 & C-I < C-II, C-III \\
\hline & & & & & & $\begin{array}{c}\text { S-II > C-II S-III > } \\
\text { C-III }\end{array}$ \\
\hline \multirow{3}{*}{$24,25(\mathrm{OH})_{2} \mathrm{D}_{3}$} & GR & 2.91 & 1,30 & 0.09 & 0.08 & $\mathrm{I}<\mathrm{II}<\mathrm{III}$ \\
\hline & UM & 49.90 & 2,60 & $0.01 * *$ & 0.62 & S-I < S-II, S-III \\
\hline & $\mathrm{GR} \times \mathrm{UM}$ & 3.72 & 2,60 & $0.02 *$ & 0.11 & $\begin{array}{c}\text { C-I }<\text { C-II, C-III } \\
\text { S }>\text { C }\end{array}$ \\
\hline \multirow{3}{*}{ 3-ерi-25(OH) $\mathrm{D}_{3}$} & GR & 7.84 & 1,30 & $0.01^{* *}$ & 0.21 & $\begin{array}{c}\text { I }<\text { II }<\text { III } \\
\text { S-I }_{-}<\mathrm{S}_{-} \mathrm{S}_{-} \mathrm{III}\end{array}$ \\
\hline & UM & 58.32 & 2,60 & $0.01 * *$ & 0.66 & $\begin{array}{l}\text { S-1 < S-II, S-III } \\
C-\mathrm{C}<\mathrm{C}-\mathrm{II} \text { - }- \text {-III }\end{array}$ \\
\hline & $\mathrm{GR} \times \mathrm{UM}$ & 7.66 & 2,60 & $0.01 * *$ & 0.20 & S-II > C-II S-III > \\
\hline \multirow{4}{*}{$25(\mathrm{OH}) \mathrm{D}_{2}$} & GR & 0.26 & 1,30 & 0.61 & 0.01 & \multirow{3}{*}{$\mathrm{I}<\mathrm{II}<\mathrm{III}$} \\
\hline & UM & 34.06 & 2,60 & $0.01^{* *}$ & 0.53 & \\
\hline & $\mathrm{GR} \times \mathrm{UM}$ & 1.05 & 2,60 & 0.35 & 0.03 & \\
\hline & & & & & & $\mathrm{S}>\mathrm{C}$ \\
\hline Ratio & GR & 6.79 & 1,30 & $0.01 *$ & 0.18 & $\begin{aligned} \mathrm{I} & <\mathrm{II}<\mathrm{III} \\
\mathrm{S}_{-} \mathrm{I} & <\mathrm{S}_{-} \mathrm{II} \mathrm{S}_{-} \mathrm{III}\end{aligned}$ \\
\hline $25(\mathrm{OH}) \mathrm{D}_{3}:$ & UM & 70.82 & 2,60 & $0.01 * *$ & 0.70 & S-I < S-II, S-III \\
\hline \multirow{2}{*}{$24,25(\mathrm{OH})_{2} \mathrm{D}_{3}$} & $\mathrm{GR} \times \mathrm{UM}$ & 8.06 & 2,60 & $0.01^{* *}$ & 0.21 & C-I, C-II < C-III \\
\hline & & & & & & C-III \\
\hline Ratio & GR & 0.06 & 1,30 & 0.81 & 0.01 & \multirow{3}{*}{ II $<$ III } \\
\hline $25(\mathrm{OH}) \mathrm{D}_{3}:$ & UM & 47.38 & 2,60 & $0.04 *$ & 0.10 & \\
\hline 3-epi-25(OH) $\mathrm{D}_{3}$ & $\mathrm{GR} \times \mathrm{UM}$ & 1.34 & 2,60 & 0.26 & 0.04 & \\
\hline
\end{tabular}

Note: GR, group; UM, ultra-marathon; $\mathrm{S}$, runners supplemented with vitamin $\mathrm{D}_{3} ; \mathrm{C}$, runners without supplementation (control group); I-24 h before the ultra-marathon; II-immediately after the ultra-marathon; III-24 $\mathrm{h}$ after the ultra-marathon. Significant difference at ${ }^{*} p \leq 0.05,{ }^{* *} p \leq 0.01$.

Furthermore, the analysis of variance of the $25(\mathrm{OH}) \mathrm{D}_{3}$ and 3-epi- $25(\mathrm{OH}) \mathrm{D}_{3}$ levels and the ratio of $25(\mathrm{OH}) \mathrm{D}_{3}$ to 3-epi-25( $\left.\mathrm{OH}\right) \mathrm{D}_{3}$ also showed a significant interaction of the group and ultra-marathon factor. An interaction analysis of the 'group' and 'ultra-marathon' factors indicated that the $25(\mathrm{OH}) \mathrm{D}_{3}$ and 3-epi-25(OH) $\mathrm{D}_{3}$ levels and the ratio of $25(\mathrm{OH}) \mathrm{D}_{3}$ to $24,25(\mathrm{OH})_{2} \mathrm{D}_{3}$ immediately after and $24 \mathrm{~h}$ after the ultra-marathon were significantly higher in the group supplemented with vitamin $\mathrm{D}_{3}$ than in the control group (Figure 3).

\section{Discussion}

The main goal of the current study was to define whether vitamin D supplementation (150,000 IU) affects vitamin D metabolism after an acute exercise, such as an ultra-marathon. We demonstrated that serum $25(\mathrm{OH}) \mathrm{D}_{3}, 24,25(\mathrm{OH})_{2} \mathrm{D}_{3}$, and 3-epi-25(OH) $\mathrm{D}_{3}$ levels significantly increased after the ultra-marathon. We also showed that in volunteers supplemented with large dose of vitamin $\mathrm{D}$, similar changes were observed after the run; however, the time of changes differed. In addition, the control experiment demonstrated that application of single high dose of vitamin D is effective in correcting vitamin D deficiency, as reported before [12]. This observation indicates that exercise in addition to supplementation modifies vitamin D metabolism.

According to several reports, vitamin $\mathrm{D}$ is stored in adipose tissue and, therefore, increased lipolysis observed during exercise, which leads to vitamin D release into the blood [30,31]. In fact, $30 \mathrm{~min}$ of cycling increases $25(\mathrm{OH}) \mathrm{D}_{3}$ levels by approximately $20 \mathrm{nmol} / \mathrm{L}$, while 5 weeks of progressive endurance exercise increases $25(\mathrm{OH}) \mathrm{D}$ levels by $2 \mathrm{nmol} / \mathrm{L}[13,32]$. We confirmed, here, these observations, as we noted almost a $20 \mathrm{nmol} / \mathrm{L}$ increase in $25(\mathrm{OH}) \mathrm{D}$ levels in the control group runners and an 
even higher increase in the vitamin D-supplemented runners. However, contrary to the findings of Sun et al. [32], in the current study, 25(OH)D levels did not return to baseline values after $24 \mathrm{~h}$ but remained elevated. Detailed analysis of individual responses revealed that in 3 of 14 runners from the control group, $25(\mathrm{OH}) \mathrm{D}_{3}$ levels did not increase and even slightly decreased. On the other hand, $25(\mathrm{OH}) \mathrm{D}_{3}$ levels did not change after the run in two runners from the vitamin D-supplemented group. This could be explained by recent studies concerning the responders and non-responders to vitamin D supplementation; however, the detailed molecular mechanism of such variable responsiveness remains to be determined [33]. It cannot be excluded that vitamin D released from adipose tissue is reabsorbed by adipose tissue, and the reabsorption is affected by exercise to a lesser degree than the release. This would explain an earlier observation of a rapid return of $25(\mathrm{OH}) \mathrm{D}_{3}$ levels after exercise to the initial value [13]. The upper body subcutaneous adipose depot is a more important source of plasma fatty acids during exercise than visceral adipose tissue [34]. In addition, visceral adipose tissue accumulates more vitamin D than subcutaneous adipose tissue [35]. Hence, subtle differences in visceral adipose tissue may significantly affect serum levels of vitamin $\mathrm{D}$ and vitamin $\mathrm{D}$ metabolism during and after exercise. In addition, the adipose tissue content of vitamin D may be significantly different between individuals (4 to $500 \mathrm{ng} / \mathrm{g}$ ) [36], which could also partially explain the different responses to the ultra-marathon.

In one study involving team-sport athletes, 12-week vitamin D supplementation resulted in increased serum $25(\mathrm{OH}) \mathrm{D}_{3}$ levels; however, a significant increase in $24,25(\mathrm{OH})_{2} \mathrm{D}_{3}$ levels was observed only after 70,000 IU of vitamin $\mathrm{D}_{3}$ was administered per week, while half of this dose had no effect [37]. Certainly, the observed effects were related to both, supplementation and training. Here, we observed a significant increase in $24,25(\mathrm{OH})_{2} \mathrm{D}_{3}$ levels in both supplemented and non-supplemented runners. This indicates an increased hydroxylation of vitamin D in C-24 position as a result of extreme exercise, such as an ultra-marathon. In addition, no direct correlation between an increase in $25(\mathrm{OH}) \mathrm{D}_{3}$ and $24,25(\mathrm{OH})_{2} \mathrm{D}_{3}$ levels was apparent in the above study [37]. That is probably associated with the activation of 24-hydroxylase after a certain cellular $25(\mathrm{OH}) \mathrm{D}_{3}$ threshold is exceeded. In the current study, $25(\mathrm{OH}) \mathrm{D}_{3}$ levels after the ultra-marathon were approximately 40 and $35 \mathrm{ng} / \mathrm{mL}$ in runners with and without supplementation, respectively. These levels were much lower than those observed in athletes supplemented with a lower dose of vitamin D (approximately $60 \mathrm{ng} / \mathrm{mL}$ ) in whom changes in $24,25(\mathrm{OH})_{2} \mathrm{D}_{3}$ levels were not observed [37]. Furthermore, the ratio of $25(\mathrm{OH}) \mathrm{D}_{3}$ to $24,25(\mathrm{OH})_{2} \mathrm{D}_{3}$ also significantly increased after the ultra-marathon, which indicated a lack of direct dependency between these two compounds, implying that the exercise stimulates the synthesis of $24,25(\mathrm{OH})_{2} \mathrm{D}_{3}$. Conversely, in the control subjects, the ratio of $25(\mathrm{OH}) \mathrm{D}_{3}$ to $24,25(\mathrm{OH})_{2} \mathrm{D}_{3}$ initially rapidly increased as a result of a faster increase in the $25(\mathrm{OH}) \mathrm{D}_{3}$ levels than that of the $24,25(\mathrm{OH})_{2} \mathrm{D}_{3}$ levels. Over time, the ratio decreased, which was associated with a further production of $24,25(\mathrm{OH})_{2} \mathrm{D}_{3}$.

Exercise induces the release of several myokines and exerkines [20,38], and some of these molecules possibly stimulate C-24 hydroxylation. However, this requires further study. The $24,25(\mathrm{OH})_{2} \mathrm{D}_{3}$ metabolite is considered to be an inactive form of vitamin D. Nevertheless, according to recent studies, this metabolite has many biological functions, including protection against $1,25(\mathrm{OH})_{2} \mathrm{D}_{3}$ toxicity, reduction in inflammation, stimulation of bone healing, and some others $[17,39]$. Hence, an increase in its levels during exercise could have important implications for the body that should be investigated in future studies.

Another metabolite, whose concentration increased after the ultra-marathon, was 3-epi-25(OH) $\mathrm{D}_{3}$. C-3 epimerization is a common metabolic pathway of major metabolites of vitamin $D_{3}$. $25(\mathrm{OH}) \mathrm{D}_{3}$ undergoes epimerization and 3-epi-25(OH) $\mathrm{D}_{3}$ is the most prevalent form [40]. The biological function of 3-epi-25- $(\mathrm{OH}) \mathrm{D}_{3}$ is not well understood. Its concentration has been reported to be in the range of $0-9.01 \mathrm{ng} / \mathrm{mL}$ [41]. In the current study, 3-epi-25-(OH) $\mathrm{D}_{3}$ was detectable before and after the ultra-marathon in all runners. Interestingly, 3-epi- $25(\mathrm{OH}) \mathrm{D}_{3}$ can be converted to 3-epi-1,25- $(\mathrm{OH}) \mathrm{D}_{3}$, which participates in the suppression of parathormone secretion without inducing hypercalcemia and induces surfactant phospholipid synthesis in pulmonary cells [15,42]. To the best of our knowledge, 
this is the first paper reporting an exercise-induced increase in 3-epi-25(OH) $\mathrm{D}_{3}$ levels. The physiological meaning of this changes remains to be determined. Further, the relative contribution of 3-epi-25(OH) $\mathrm{D}_{3}$ to serum vitamin $\mathrm{D}$ does not correlate with $25(\mathrm{OH}) \mathrm{D}_{3}$ levels in individuals with hypervitaminosis $\mathrm{D}$ [43]. Conversely, here, we showed a decrease in the ratio of $25(\mathrm{OH}) \mathrm{D}_{3}$ to $3-e p i-25(\mathrm{OH}) \mathrm{D}_{3}$ after the run or supplementation, indicating that increased serum $25(\mathrm{OH}) \mathrm{D}_{3}$ levels lead to a rise in $\mathrm{C}-3$ epimerization. Hence, epimerization may be the first line of defense of the body against high levels of $25(\mathrm{OH}) \mathrm{D}_{3}$, since epimeric forms of $1,25(\mathrm{OH})_{2} \mathrm{D}_{3}$ are considered to be less biologically active than native forms.

The consumption of vitamins during an ultra-marathon is a common nutritional habit and, along with the growing interest in this type of physical activity, has been studied [44,45]. It should be highlighted that intake of typical antioxidants, such as vitamins $C$ and $E$, as anti-inflammatory and antioxidative factors in endurance training could even blunt training adaptations and attenuate some of the cellular adaptations in skeletal muscle [46]. Furthermore consumption of those vitamins did not affect physiological aspects related to sport performance and did not improve sport results [47]. That is why there is a need for searching for proper supplementation methods, where vitamin D supplementation can be beneficial for ultra-marathon runners' health.

In conclusion, this is the first report demonstrating that endurance exercise significantly increases serum levels of $24,25(\mathrm{OH})_{2} \mathrm{D}_{3}, 3-$ epi- $25(\mathrm{OH}) \mathrm{D}_{3}$, and $25(\mathrm{OH}) \mathrm{D}_{3}$, possibly by liberating vitamin $\mathrm{D}$ from adipose tissue and stimulating its metabolism. These observations imply that formation of vitamin $\mathrm{D}$ metabolites can, on the one hand, protect from vitamin D toxicity, and on the other hand, they can exert some other biological functions, e.g., anti- inflammatory and antioxidative. All of these data indicate that these changes in vitamin D metabolism are a physiological response to endurance exercise. The changes are affected by vitamin D status; thus, one can predict that low adipose or skeletal muscle vitamin stores may negatively influence physiological response to exercise. However, more work is needed to explore the role of vitamin D metabolites in physiological response to exercise.

Author Contributions: Conceptualization, J.M., M.A.Ż. and J.A.; data curation, J.M.; formal analysis, J.M., A.K., B.N., K.K., R.R. and T.B.; investigation, J.M., B.S., T.K. and K.K.; methodology, J.M., B.S., B.N., K.K., R.R. and T.B.; project administration, A.K.; supervision, J.M.; validation, M.A.Ż.; writing一original draft, J.M., B.S., K.K., R.R. and J.A.; writing-review and editing, J.M., A.K., B.N., T.K., M.A.Ż., T.B. and J.A. All authors have read and agreed to the published version of the manuscript.

Funding: This research was funded by the Knowledge Grant of the Polish Ministry of Science and Higher Education (number NRSA 406754).

Acknowledgments: We gratefully acknowledge all the participants involved in the experiment. We also thank the Mountain Marathons Foundation (Kudowa-Zdrój), Piotr Hercog, and Przemysław Zabecki. The authors would like to thank Joanna Mackie for language assistant.

Conflicts of Interest: The authors declare no conflict of interest. The funders had no role in the design of the study; in the collection, analyses, or interpretation of data; in the writing of the manuscript, or in the decision to publish the results.

\section{References}

1. Wang, Y.; Zhu, J.; DeLuca, H.F. Where is the vitamin D receptor? Arch. Biochem. Biophys. 2012, 523, $123-133$. [CrossRef] [PubMed]

2. Wierzbicka, J.; Piotrowska, A.; Żmijewski, M.A. The renaissance of vitamin D. Acta Biochim. Pol. 2014, 61, 679-686. [CrossRef] [PubMed]

3. Wierzbicka, E.; Szalecki, M.; Pludowski, P.; Jaworski, M.; Brzozowska, A. Vitamin D status, body composition and glycemic control in Polish adolescents with type 1 diabetes. Minerva Endocrinol. 2016, 41, 445-455. [PubMed]

4. Strange, R.C.; Shipman, K.E.; Ramachandran, S. Metabolic syndrome: A review of the role of vitamin D in mediating susceptibility and outcome. World J. Diabetes 2015, 6, 896-911. [CrossRef] [PubMed]

5. Prasad, P.; Kochhar, A. Interplay of vitamin D and metabolic syndrome: A review. Diabetes Metab. Syndr. 2016, 10, 105-112. [CrossRef] 
6. Pludowski, P.; Jaworski, M.; Niemirska, A.; Litwin, M.; Szalecki, M.; Karczmarewicz, E.; Michalkiewicz, J. Vitamin D status, body composition and hypertensive target organ damage in primary hypertension. J. Steroid Biochem. Mol. Biol. 2014, 144, 180-184. [CrossRef]

7. De la Puente Yague, M.; Collado Yurrita, L.; Ciudad Cabanas, M.J.; Cuadrado Cenzual, M.A. Role of Vitamin D in Athletes and Their Performance: Current Concepts and New Trends. Nutrients 2020, 12, 579. [CrossRef]

8. Ogan, D.; Pritchett, K. Vitamin D and the athlete: Risks, recommendations, and benefits. Nutrients 2013, 5, 1856-1868. [CrossRef]

9. Janssen, H.C.; Emmelot-Vonk, M.H.; Verhaar, H.J.; van der Schouw, Y.T. Determinants of vitamin D status in healthy men and women aged 40-80 years. Maturitas 2013, 74, 79-83. [CrossRef]

10. Theuri, G.; Kiplamai, F. Association between vitamin D levels and central adiposity in an eastern Africa outpatient clinical population. Dermatoendocrinol 2013, 5, 218-221. [CrossRef]

11. Bescos Garcia, R.; Rodriguez Guisado, F.A. Low levels of vitamin D in professional basketball players after wintertime: Relationship with dietary intake of vitamin D and calcium. Nutr. Hosp. 2011, 26, 945-951. [CrossRef] [PubMed]

12. Mentaverri, R.; Souberbielle, J.C.; Brami, G.; Daniel, C.; Fardellone, P. Pharmacokinetics of a New Pharmaceutical Form of Vitamin D3 100,000 IU in Soft Capsule. Nutrients 2019, 11, 703. [CrossRef] [PubMed]

13. Sun, X.; Cao, Z.B.; Taniguchi, H.; Tanisawa, K.; Higuchi, M. Effect of an Acute Bout of Endurance Exercise on Serum 25(OH)D Concentrations in Young Adults. J. Clin. Endocrinol. Metab. 2017, 102, 3937-3944. [CrossRef] [PubMed]

14. Lutsey, P.L.; Eckfeldt, J.H.; Ogagarue, E.R.; Folsom, A.R.; Michos, E.D.; Gross, M. The 25-hydroxyvitamin D3 C-3 epimer: Distribution, correlates, and reclassification of 25-hydroxyvitamin D status in the population-based Atherosclerosis Risk in Communities Study (ARIC). Clin. Chim. Acta 2015, 442, 75-81. [CrossRef] [PubMed]

15. Brown, A.J.; Ritter, C.S.; Weiskopf, A.S.; Vouros, P.; Sasso, G.J.; Uskokovic, M.R.; Wang, G.; Reddy, G.S. Isolation and identification of 1alpha-hydroxy-3-epi-vitamin D3, a potent suppressor of parathyroid hormone secretion. J. Cell. Biochem. 2005, 96, 569-578. [CrossRef] [PubMed]

16. Nemere, I.; Wilson, C.; Jensen, W.; Steinbeck, M.; Rohe, B.; Farach-Carson, M.C. Mechanism of 24,25-dihydroxyvitamin D3-mediated inhibition of rapid, 1,25-dihydroxyvitamin D3-induced responses: Role of reactive oxygen species. J. Cell. Biochem. 2006, 99, 1572-1581. [CrossRef]

17. Seo, E.G.; Einhorn, T.A.; Norman, A.W. 24R,25-dihydroxyvitamin D3: An essential vitamin D3 metabolite for both normal bone integrity and healing of tibial fracture in chicks. Endocrinology 1997, 138, 3864-3872. [CrossRef]

18. Seo, E.G.; Norman, A.W. Three-fold induction of renal 25-hydroxyvitamin D3-24-hydroxylase activity and increased serum 24,25-dihydroxyvitamin D3 levels are correlated with the healing process after chick tibial fracture. J. Bone Miner. Res. 1997, 12, 598-606. [CrossRef]

19. Weinstock-Guttman, B.; Zivadinov, R.; Qu, J.; Cookfair, D.; Duan, X.; Bang, E.; Bergsland, N.; Hussein, S.; Cherneva, M.; Willis, L.; et al. Vitamin D metabolites are associated with clinical and MRI outcomes in multiple sclerosis patients. J. Neurol. Neurosurg. Psychiatry 2011, 82, 189-195. [CrossRef]

20. Safdar, A.; Tarnopolsky, M.A. Exosomes as Mediators of the Systemic Adaptations to Endurance Exercise. Cold Spring Harb. Perspect. Med. 2018, 8. [CrossRef]

21. Li, D.J.; Fu, H.; Zhao, T.; Ni, M.; Shen, F.M. Exercise-stimulated FGF23 promotes exercise performance via controlling the excess reactive oxygen species production and enhancing mitochondrial function in skeletal muscle. Metabolism 2016, 65, 747-756. [CrossRef] [PubMed]

22. Shimada, T.; Hasegawa, H.; Yamazaki, Y.; Muto, T.; Hino, R.; Takeuchi, Y.; Fujita, T.; Nakahara, K.; Fukumoto, S.; Yamashita, T. FGF-23 is a potent regulator of vitamin D metabolism and phosphate homeostasis. J. Bone Miner. Res. 2004, 19, 429-435. [CrossRef]

23. Kasprowicz, K.; Ratkowski, W.; Wolyniec, W.; Kaczmarczyk, M.; Witek, K.; Zmijewski, P.; Renke, M.; Jastrzebski, Z.; Rosemann, T.; Nikolaidis, P.T.; et al. The Effect of Vitamin D3 Supplementation on Hepcidin, Iron, and IL-6 Responses after a 100 km Ultra-Marathon. Int. J. Environ. Res. Public Health 2020, 17, 2962. [CrossRef] [PubMed]

24. Hoffman, M.D.; Ong, J.C.; Wang, G. Historical analysis of participation in $161 \mathrm{~km}$ ultramarathons in North America. Int. J. Hist. Sport 2010, 27, 1877-1891. [CrossRef] [PubMed] 
25. Knechtle, B.; Nikolaidis, P.T. Physiology and Pathophysiology in Ultra-Marathon Running. Front. Physiol. 2018, 9, 634. [CrossRef]

26. Tiller, N.B.; Roberts, J.D.; Beasley, L.; Chapman, S.; Pinto, J.M.; Smith, L.; Wiffin, M.; Russell, M.; Sparks, S.A.; Duckworth, L.; et al. International Society of Sports Nutrition Position Stand: Nutritional considerations for single-stage ultra-marathon training and racing. J. Int. Soc. Sports Nutr. 2019, 16, 50. [CrossRef]

27. Rola, R.; Kowalski, K.; Bienkowski, T.; Studzinska, S. Improved sample preparation method for fast LC-MS/MS analysis of vitamin D metabolites in serum. J. Pharm. Biomed. Anal. 2020, 190, 113529. [CrossRef]

28. Van Beaumont, W. Evaluation of hemoconcentration from hematocrit measurements. J. Appl. Physiol. 1972, 32, 712-713. [CrossRef]

29. Sherk, V.D.; Chrisman, C.; Smith, J.; Young, K.C.; Singh, H.; Bemben, M.G.; Bemben, D.A. Acute bone marker responses to whole-body vibration and resistance exercise in young women. J. Clin. Densitom. 2013, 16, 104-109. [CrossRef]

30. Blum, M.; Dolnikowski, G.; Seyoum, E.; Harris, S.S.; Booth, S.L.; Peterson, J.; Saltzman, E.; Dawson-Hughes, B. Vitamin D(3) in fat tissue. Endocrine 2008, 33, 90-94. [CrossRef]

31. Blum, M.; Dallal, G.E.; Dawson-Hughes, B. Body size and serum 25 hydroxy vitamin D response to oral supplements in healthy older adults. J. Am. Coll. Nutr. 2008, 27, 274-279. [CrossRef] [PubMed]

32. Sun, X.; Cao, Z.B.; Tanisawa, K.; Taniguchi, H.; Kubo, T.; Higuchi, M. Effects of chronic endurance exercise training on serum 25(OH)D concentrations in elderly Japanese men. Endocrine 2018, 59, 330-337. [CrossRef] [PubMed]

33. Seuter, S.; Virtanen, J.K.; Nurmi, T.; Pihlajamäki, J.; Mursu, J.; Voutilainen, S.; Tuomainen, T.P.; Neme, A.; Carlberg, C. Molecular evaluation of vitamin D responsiveness of healthy young adults. J. Steroid Biochem. Mol. Biol. 2017, 174, 314-321. [CrossRef]

34. Votruba, S.B.; Jensen, M.D. Regional fat deposition as a factor in FFA metabolism. Annu. Rev. Nutr. 2007, 27, 149-163. [CrossRef] [PubMed]

35. Carrelli, A.; Bucovsky, M.; Horst, R.; Cremers, S.; Zhang, C.; Bessler, M.; Schrope, B.; Evanko, J.; Blanco, J.; Silverberg, S.J.; et al. Vitamin D Storage in Adipose Tissue of Obese and Normal Weight Women. J. Bone Miner. Res. 2017, 32, 237-242. [CrossRef] [PubMed]

36. Didriksen, A.; Burild, A.; Jakobsen, J.; Fuskevag, O.M.; Jorde, R. Vitamin D3 increases in abdominal subcutaneous fat tissue after supplementation with vitamin D3. Eur. J. Endocrinol. 2015, 172, 235-241. [CrossRef] [PubMed]

37. Owens, D.J.; Tang, J.C.; Bradley, W.J.; Sparks, A.S.; Fraser, W.D.; Morton, J.P.; Close, G.L. Efficacy of High-Dose Vitamin D Supplements for Elite Athletes. Med. Sci. Sports Exerc. 2017, 49, 349-356. [CrossRef]

38. Pedersen, B.K. Physical activity and muscle-brain crosstalk. Nat. Rev. Endocrinol. 2019, 15, $383-392$. [CrossRef]

39. Chen, Y.; Kong, J.; Sun, T.; Li, G.; Szeto, F.L.; Liu, W.; Deb, D.K.; Wang, Y.; Zhao, Q.; Thadhani, R.; et al. 1,25-Dihydroxyvitamin $\mathrm{D}(3)$ suppresses inflammation-induced expression of plasminogen activator inhibitor-1 by blocking nuclear factor-kappaB activation. Arch. Biochem. Biophys. 2011, 507, 241-247. [CrossRef]

40. Singh, R.J.; Taylor, R.L.; Reddy, G.S.; Grebe, S.K. C-3 epimers can account for a significant proportion of total circulating 25-hydroxyvitamin D in infants, complicating accurate measurement and interpretation of vitamin D status. J. Clin. Endocrinol. Metab. 2006, 91, 3055-3061. [CrossRef]

41. Bailey, D.; Veljkovic, K.; Yazdanpanah, M.; Adeli, K. Analytical measurement and clinical relevance of vitamin D(3) C3-epimer. Clin. Biochem. 2013, 46, 190-196. [CrossRef] [PubMed]

42. Rehan, V.K.; Torday, J.S.; Peleg, S.; Gennaro, L.; Vouros, P.; Padbury, J.; Rao, D.S.; Reddy, G.S. 1Alpha,25-dihydroxy-3-epi-vitamin D3, a natural metabolite of 1alpha,25-dihydroxy vitamin D3: Production and biological activity studies in pulmonary alveolar type II cells. Mol. Genet. Metab. 2002, 76, 46-56. [CrossRef]

43. Granado-Lorencio, F.; Blanco-Navarro, I.; Perez-Sacristan, B.; Donoso-Navarro, E.; Silvestre-Mardomingo, R. Serum levels of 3-epi-25-OH-D3 during hypervitaminosis D in clinical practice. J. Clin. Endocrinol. Metab. 2012, 97, E2266-E2270. [CrossRef] [PubMed]

44. Nikolaidis, P.T.; Veniamakis, E.; Rosemann, T.; Knechtle, B. Nutrition in Ultra-Endurance: State of the Art. Nutrients 2018, 10, 1995. [CrossRef] 
45. Knez, W.L.; Peake, J.M. The prevalence of vitamin supplementation in ultraendurance triathletes. Int. J. Sport Nutr. Exerc. Metab. 2010, 20, 507-514. [CrossRef] [PubMed]

46. Costa, R.J.S.; Knechtle, B.; Tarnopolsky, M.; Hoffman, M.D. Nutrition for Ultramarathon Running: Trail, Track, and Road. Int. J. Sport Nutr. Exerc. Metab. 2019, 29, 130-140. [CrossRef] [PubMed]

47. Taghiyar, M.; Ghiasvand, R.; Askari, G.; Feizi, A.; Hariri, M.; Mashhadi, N.S.; Darvishi, L. The effect of vitamins $\mathrm{C}$ and e supplementation on muscle damage, performance, and body composition in athlete women: A clinical trial. Int. J. Prev. Med. 2013, 4, S24-S30.

Publisher's Note: MDPI stays neutral with regard to jurisdictional claims in published maps and institutional affiliations.

(C) 2020 by the authors. Licensee MDPI, Basel, Switzerland. This article is an open access article distributed under the terms and conditions of the Creative Commons Attribution (CC BY) license (http://creativecommons.org/licenses/by/4.0/). 